We agree with Dr Laroche and her colleagues and with Dr G M Cochrane and his colleagues (1 June, p 1608) that home nebulisers should be prescribed only when other treatment has proved unsatisfactory and that full instruction and free access to further advice are necessary. Hospital prescriptions and letters to general practitioners should spell out full details of drug (name, concentration (if a solution), and dose in $\mathrm{mg}$ and $\mathrm{ml}$ ); diluent (name, concentration, and volume); and frequency of administration and should also mention important aspects of the care of home nebulisers and the requirement for disposable needles and syringes, which are not available on NHS prescriptions at present.

D C CURrie P J COLE

Host Defence Unit,

Department of Medicine

Cardiothoracic Institute,

Brompton Hospital,

London SW3 6HP

\section{Risk factors for premature death in middle aged men}

SIR,-As the coauthor responsible for the hypertensive population in the study first published in the $B M \mathcal{F}$ (28 April 1984, p 1264) and mentioned in your notice of inadvertent duplicate publication (1 June, p 1627) I should like to underline that I have no responsibility whatsoever for the publication in the American fournal of Medicine later that year, which, I agree, substantially refers to the same population. The fact that my name was not included in the later paper underlines the point that I had no knowledge about this duplication.

I am in fact very much against the policy of double or even triple publishing, which unfortunately seems to have increased in prevalence recently, and I can only support the comments made in your notice on scientific ethical rules.

Department of Medicine,

NeLS HENNINGSEN

Malmö General Hosf

Sweden

\section{Towards quality in general practice}

SIR,-While in favour of improving the quality of general practice (RCGP report, 29 June, p 1981), I feel this must be done by consensus within the specialty and not be imposed on us by those who consider themselves our leaders. The consultants merit award system, which is secret and endorsed by a small group of senior colleagues, smacks of "awards for the boys," and grading GPs into good and bad would evoke feelings of revulsion by most actively practising GPs if it were organised on similar lines.

We know that this government, seeing any saving to be made by introducing such a scheme, would pounce on it, especially as the RCGP is pushing hard for financial penalties for "poor quality" GPs. The only acceptable way to evaluate GPs would be by a set of fixed criteria. Points could be awarded for agreed items of good practice, such as ordered record keeping, use of ancillary staff, age-sex and disease registers, and screening-for diabetes, hypertension, paediatric development, cervical smears, and so on. There are obviously other criteria that can be added to this list.

There must be no evaluation by opinion organised by so called peers, with whom many of us disagree as to what constitutes a good GP. If there are fixed criteria agreed by the majority of GPs we might be able to accept awards for good practice. We should never accept them if they are organised by a group of self imposed academic GPs on an examination, reassessment, or peer review system or by a government whose overriding interest appears to be saving money in the NHS.

GPs who feel strongly about the proposals by the college should make their feelings known to their representatives both in the college and in the local medical committees.

A INWALD

London N19 3RN

\section{AIDS-the African connection?}

SIR,-As national spokesman for the American plasmapheresis industry, I would like to refute the judgments expressed by Dr Peter Jones (23 March, p 932).

Overall, Dr Jones's opinions are factually and scientifically incorrect. His suggestion that the American commercial plasma products industry relies on plasma from outside the United States, primarily from Africa, and that such plasma is the route for the transmission of the acquired immune deficiency syndrome (AIDS), not sexual contact, cannot be supported by the facts. He also charges that the industry is secretive, disregards the World Health Organisation, and condemns national goals for blood product self sufficiency

All of his claims are untrue. Here are a few critical facts. US manufacturers must be licensed by the US Food and Drug Administration. As such, they are restrained as to their sources of plasma, and it can easily be verified that they do not rely on plasma from Africa. If, as Dr Jones suggests, AIDS was introduced into the US by foreign plasma and not from sexual contact, you would expect to see the disease only in the recipients of plasma. In the US there are now over 10000 cases of AIDS; less than $2 \%$ have implicated the transfusion of blood products as the route of transmission of the virus.

Regarding the industry's attitude toward the WHO, national self sufficiency, and sharing information about its activities, consider the following. Industry representatives are supportive of and participate in WHO working groups which consider issues affecting biological products.

On self sufficiency, the industry has a record of fulfilling a partnership role with national blood services meeting the blood product needs unmet by local programmes and, in some cases, serving as consultants and advisers to national blood service programmes on technical and manufacturing concerns of the national services. Without the commercial supply, thousands of haemophiliacs would suffer or die. World wide the industry supplies over $80 \%$ of coagulation product needs.

On sharing information, the American Blood Resources Association annually hosts an open public forum, which includes the presentation of detailed information on the collection manufacture, and supply of plasma and plasma products. The transcripts of these meetings have always been available to the public.

It is unfortunate that Dr Jones did not check his facts first. The publication of such inaccurate information discredits his otherwise fine reputation and discredits the commercial industry which strives to meet a diversity of national blood product requirements with the highest quality of products. Perhaps, most importantly, it imposes unwarranted anguish and suffering on the very people whom Dr Jones and the industry are trying to serve-the haemophiliacs.

American Blood Resources Association,

ROBERT W REILLY

Annapolis, Maryland 21403,

USA

** Dr Jones's reply follows.-ED, $B M \mathcal{F}$.
SIR,-At a time when those who provide health care should be keeping an open mind about the origins, causes, and modes of transmission of the acquired immune deficiency syndrome (AIDS) it is sad that a senior spokesman for the plasma industry should fail to answer the questions I raised. Mr Reilly ought to be aware that all that the major companies engaged in the collection and fractionation of plasma have to do in order not to be bound by FDA rules is to set up subsidiaries outwith the United States. Examples known to regulatory bodies in Britain and other countries include the longstanding contract between a multinational company and a plasmapheresis centre in Lesotho in Africa and the facilities run by at least two companies in Mexico.

Mr Reilly's contention that AIDS could not have been introduced into the United States via blood products because of the low incidence of related disease is untenable. The public might have been saved from catastrophe only because albumin has always been heat treated, and fortuitously it is heat treatment that has been shown to destroy the human $\mathrm{T}$ cell lymphotropic virus type III. $\mathrm{Mr}$ Reilly fails to assure doctors working outside the United States, as Dr E D Acheson has done for the United Kingdom (13 April, p 1145), that plasma donation from high risk areas is no longer happening. Perhaps his reticence in doing so reflects the fact that at least five law suits have already been filed in his country.

In his letter Mr Reilly takes pride in reporting that his industry supplies over $80 \%$ of coagulation product needs world wide. This fact alone could account for the ease with which a disease like AIDS has spread within the haemophilic population. We know that not only are the commercial therapeutic materials contaminated but that American laboratory reagents also contain the HTLV-III virus. ${ }^{1}$

I still think that the possibility of spread from Africa through blood products deserves consideration in our understanding of the epidemiology of AIDS. Quite apart from the collection and distribution of plasma by the commercial companies, the legitimate importation of red cells from Europe into the United States should be considered as a possible vehicle because of the close links between the citizens of some European countries where the present incidence of AIDS is unexpectedly high and central Africa.

Peter Jones

Northern Regional Haemophilia Service,

Royal Victoria Infirmary

Newcastle upon Tyne NE1 4LP

1 Jones P, Hamilton PJ, Oxley A, Codd A, Tedder R. Anti-HTLV III positive laboratory reagerits. Lancet 1985;i: 1458-9.

\section{The GMC and apartheid}

SIR,-Mr David Delvin (15 June, p 1828) quotes 1982 data in support of what appears to be a rather belated moral indignation. The available 1983 and 1984 data would have shown that the students (other than white) who were admitted to the MB, ChB course in 1978 at our faculty have since completed their course. Naturally, the 51 students at present in the course would not in future allow of an opportunity to put the 1982 data to misleading use.

No doubt the GMC could provide your correspondent with factual information as to our selection policy. In reply to its questionnaires in the past we said: in 1982, "For the selection of undergraduate medical students their academic achievements are taken into consideration. Applicants are divided into the following categories: (a) matriculants, (b) matriculates, (c) post- 